\title{
PENINGKATAN BUDAYA KESELAMATAN PASIEN OLEH PERAWAT DI Rumah Sakit
}

\section{Dwi Syafriningsih}

Email: dwisyafriningsih@gmail.com

\begin{abstract}
Latar Belakang
Budaya keselamatan pasien dapat diukur melalui standar pengukuran budaya keselamatan pasien yang dikembangkan beberapa organisasi dalam memberikan suatu pelayanan yang aman dan bebas dari cedera. Budaya keselamatan pasien yang menjadi output terhadap nilai-nilai, sikap, kompetensi dan juga pola kebiasaan yang menggambarkan komitmen dan kemampuan dalam berorganisasi. Budaya keselamatan pasien merupakan suatu hal yang penting untuk membangun program keselamatan pasien secara menyeluruh. Jadi tidak hanya berfokus lada programnya saja, namun harus lebih memfokuskan pada budaya keselamatan pasien agar hasil yang didapat menjadi maksimal.
\end{abstract}

Teori Reason mengungkapkan bahwa insiden keselamatan pasien disebabkan oleh dua faktor, faktor pertama kesalahan laten dan faktor kedua kesalahan aktif. Kesalahan laten terkait dengan insiden keselamatan pasien meliputi lingkungan eksternal, manajemen, lingkungan sosial atau organisasi, lingkungan fisik, interaksi antara manusia dan sistem. Budaya keselamatan merupakan bagian dari kesalahan laten yang terkait dengan manajemen, sedangkan indikator budaya keselamatan meliputi kerja sama, komunikasi, kepemimpinan, pelaporan dan respon terhadap kesalahan tidak menghukum. Kunci dari pencegahan cedera dalam pelayanan keperawatan yaitu identifikasi risiko. Hal ini sangat tergantung pada budaya kepercayaan, kejujuran, integritas, dan keterbukaan berkomunikasi dalam sistem asuhan keperawatan.

Dalam membangun budaya keselamatan pasien seluruh staf rumah sakit dapat meningkatkan keselamatan pasien dengan didukung oleh peran kepala ruangan yang optimal. Upaya kepala ruangan dalam melaksanakan peran yang efektif diruangannya dapat mempengaruhi budaya keselamatan pasien. 


\section{Metode}

Metode dalam penulisan ini menggunakan metode kualitatif, yaitu merupakan metode yang sifatnya memberikan suatu penjelasan dengan analisis. Metode ini bersifat subjektif, yaitu proses penelitian yang lebih fokus pada landasan teori. Metode yang digunakan dalam kajian ini adalah Literature review. Metode ini menganalisis, eksplorasi dan kajian bebas pada artikel, jurnal, maupun ebook yang releven dan berfokus pada metode pembelajaran klinik yang mempengaruhi kemampuan mahasiswa dalam meningkatkan budaya keselamatan pasien. Adapun artikel yang digunakan pada literature review ini adalah artikel yang didapatkan dengan memuat 3 database Pubmed, Geogle Scholar dan Science Direct.

\section{Hasil}

Berdasarkan hasil pencarian literature didapatkan bahwa dengan meningkatkan budaya keselamatan pasien oleh perawat dapat meningkatkan kemampuan mahasiswa untuk lebih kritis dalam menerapkan k3 dalam melakukan tindakan. Keselamatan dan kesehatan kerja merupakan hal yang penting, karena dampak kecelakaan dan penyakit kerja tidak hanya merugikan perawat, tetapi juga rumah sakit baik secara langsung maupun tidak langsung. Budaya keselamatan yang meliputi kerja sama, komunikasi, kepemimpinan, pelaporan dan respon tidak menghukum terhadap kesalahan didapatkan hasil.

Pada kerja sama adalah indikator pertama dalam budaya keselamatan pasien. Berdasarkan hasil dari penelitian sebesar 64,6\% dalam melakukan tindakan asuhan keperawatan selalu bekerja sama dengan sesama perawat maupun dengan tenaga kesehatan lainnya dengan baik. Kemudiam pada komunikasi dari hasil penelitian literature didapatkan sebesar (54,0\%) telah melakukan budaya komunikasi dengan baik. Lalu pada kepemimpinan dari hasil penelitian literature didapatkan hasil sebesar 91,2\% sudah menerapkan cara kepemimpinan yang baik. Pada bagian pelaporan didapatkan hasil yaitu sebesar 61,9\% dalam budaya keselamatan pasien dan berada pada kategori cukup. Dan pada respon tidak menghukum terhadap kesalahan dalam budaya keselamatan pasien didapatkan sebesar 51,3\% dan sama seperti pelaporan dikategorikan dalam kategori cukup.

Menurut The Health Foudation, 2011, budaya keselamatan berhubungan dengan sejauh mana organisasi tersebut memprioritaskan dan mendukung dalam 
upaya peningkatan keselamatan dengan aman. Organisasi dan budaya keselamatan positif memiliki komunikasi atas dasar saling percaya, persepsi bersama tentang pentingnya keselamatan, keyakinan pada efektivitas langkah-langkah pencegahan, dan dukungan bagi tenaga kerja.

\section{Pembahasan}

Budaya keselamatan pasien adalah salah satu faktor penting yang dapat mempengaruhi keselamatan pasien. Budaya keselamatan pasien yang baik akan membuat implementasi keselamatan pasien menjadi baik. Menurut Cahyono (2008), budaya keselamatan pasien adalah fondasi keselamatan pasien. Membangun budaya keselamatan pasien merupakan kata kunci terwujudnya pelayanan yang bermutu dan aman.

Budaya keselamatan pasien yang baik penting di terapkan karena merupakan unsur dari keselamatan pasien. Dan akan semakin baik bila perawat mempunyai kesadaran akan pentingnya keselamatan pasien, pengetahuan, kerjasama tim yang baik, serta motivasi dalam meningkatkan keselamatan pasien dengan menerapkan budaya keselamatan pasien. Dengan melaksanakan pelatihan atau seminar mengenai keselamatan pasien sangat diperlukan agar dapat menambah wawasan dan pengetahuan perawat pelaksana sehingga penerapan budaya keselamatan pasien dapat diterapkan lebih baik lagi untuk meningkatkan kualitas dan mutu pelayanan keperawatan. Dalam penerapan budaya keselamatan pasien sangat penting dalam meningkatkan mutu pelayanan rumah sakit juga. Budaya keselamatan pasien juga meliputi :

\section{Kerja sama}

Kerjasama adalah hal yang pertama dari budaya keselamatan pasien. Dalam melakukan asuhan keperawatan kepada pasien, perawat pasti selalu membutuhkan bantuan dari perawat maupun tenaga kesehatan yang lainnya. Bentuk kerjasama yang diberikan tidak hanya berupa saling membantu pekerjaan ketika perawat dihadapkan pada tugas yang sangat banyak dan membutuhkan penyelesaian yang secepat mungkin, namun juga bisa berupa pembagian tugas berdasarkan kelompok kecil atau tim dalam satu unit ruang rawat inap. Perawat merupakan petugas kesehatan dengan waktu kerja paling lama yang memberikan pelayanan 24 jam secara terus menerus.

\section{Komunikasi}


Komunikasi sangatlah penting dalam setiap melakukan tindakan asuhan keperawatan pada pasien. Komunikasi yang baik dan benar perlu dilakukan untuk mengkoordinasikan asuhan keperawatan yang melibatkan banyak profesi selain profesi perawat. Komuniasi dalam praktek keperawatan merupakan hal penting bagi perawat. Dalam melaksanakan asuhan keperawatan untuk mendapatkan hasil yang optimal. Perawat harus memiliki peran yang paling dominan dalam upaya mencegah terjadinya kesalahan dalam pengobatan, termasuk pelaporan insiden.

Mendidik diri sendiri dan juga perawat lain tentang pentingnya komunikasi, memberikan usulan untuk perubahan pada prosedur dan kebijakan serta keterlibatan dalam melakukan identifikasi permasalahan. Kesalahan medis jarang disebabkan oleh faktor kesalahan manusia secara individual, tetapi lebih kepada dikarena kesalahan pada saat melakukan komunikasi yang menyebabkan terputusnya rantai dalam sistem tersebut.

Hal ini menunjukkan pentingnya menjalin komunikasi dengan baik dan benar agar informasi yang disampaikan jelas dan juga tidak terputus yang mengakibatkan kerugian pada pasien. Informasi mengenai keselamatan pasien perlu diketahui oleh semua perawat yang memberikan asuhan keperwatan. Hal tersebut berfungsi untuk mencegah perawat melakukan tindakan yang dapat menyebabkan cidera pada pasien. Komunikasi merupakan kunci sukses dalam melakukan interaksi dalam kehidupan berorganisasi.

\section{Kepemimpinan}

Pemimpin harus memiliki komitmen yang kuat terhadap keselamatan pasien, sehingga keselamatan pasien menjadi hal yang paling utama dalam memberikan pelayanan keperawatan. Pemimpin juga harus mampu menjadi contoh perubahan bagi anggotanya dengan melaksanakan program keselamatan pasien. Pimpinan mendorong dan menjamin implementasi program keselamatan pasien. Pemimpin harus membangun komitmen dan fokus yang kuat dan jelas untuk mendukung anggotanya dalam menjalankan program keselamatan pasien secara berkesinambungan, memprioritaskan program keselamatan pasien dalam setiap rapat dengan para pengambil keputusan. Pimpinan harus menjamin berlangsungnya program proaktif untuk identifikasi risiko keselamatan pasien dan program menekan atau mengurangi Kejadian Tidak Diharapkan. Pimpinan mendorong dan 
menumbuhkan komunikasi dan koordinasi antar unit dan individu yang berkaitan dengan pengambilan keputusan tentang keselamatan pasien. Pimpinan mengalokasikan sumber daya yang adekuat untuk mengukur, mengkaji, dan meningkatkan kinerja rumah sakit serta meningkatkan keselamatan pasien. Pimpinan mengukur dan mengkaji efektifitas kontribusinya dalam meningkatkan kinerja rumah sakit dan keselamatan pasien.

\section{Pelaporan}

Pelaporan dalam penerapan budaya keselamatan pasien berada dalam kategori cukup. Perawat diwajibkan melaporkan kejadian kesalahan yang tidak disengaja dan kondisi yang mengakibatkan cedera yang dapat dicegah pada pasien, yang terdiri dari kejadian tidak diharapkan, kejadian nyaris cedera, kejadian tidak cedera dan kejadian potensial cedera.

Melaporkan sebuah kejadian atau insiden keselamatan pasien masih jarang dilakukan atau pun bahkan jika ada pelaporan tentang insiden atau kejadian keselamatan pasien belum ada pelaporan secara resmi. Hal ini disebabkan para perawat takut untuk melaporkan insiden yang terjadi pada pasien karena kesalahan yang dilakukannya. Perawat merasa takut akan hukuman dari penyedia atas kesalahan yang telah ia lakukan saat melakukan asuhan keperawatan. Pada hakikatnya pelaporan insiden keselamatan pasien sangat dibutuhkan oleh semua pihak untuk perbaikan pelayanan dalam hal ini khususnya asuhan keperawatan. Informasi dari pelaporan insiden keselamatan pasien yang akurat dan jelas dapat membantu identifikasi akar permasalahan bagaimana insiden tersebut bisa terjadi serta identifikasi faktor risiko sehingga insiden yang sama dapat dicegah untuk kemudian hari. Peran dan fungsi perawat yang salah satunya yaitu peran sebagai peneliti. Informasi yang benar dan jelas yang diperoleh dari sistem pelaporan, asesmen risiko, kajian insiden, dan audit serta analisis, digunakan untuk menentukan solusi.

5. Respon tidak menghukum terhadap kesalahan

Respon tidak menghukum terhadap kesalahan ini menunjukkan bahwa dimasa yang akan datang pelaporan terhadap insiden keselamatan pasien tidak sematamata hanya berupa pelaporan insiden keselamatan, namun pelaporan tersebut hendaknya ditindaklanjuti untuk memperbaiki kesalahan dan mencari akar permasalahan, tidak untuk menghukum 
perawat yang melakukan kesalahan atau berpengaruh terhadap penilainan kinerjanya.

Ketika kesalahan dilaporkan, maka cukup melaporkan masalah sendiri dilaporkan menemukan jalan keluar tidak menunjukkan siapa pelaku harus dihukum. Belajar dari insiden keselamatan pasien hanya akan berhasil jika setiap permasalahan tidak dilihat sebagai kesalahan individu tetapi harus diperhatikan dengan pendekatan sistem dan pemahaman faktor manusia. Seperti yang diatur dalam Peraturan Menteri Kesehatan Republik Indonesia nomer 755/Menkes/Per/IV/2011 tentang pelaksanaan komite medis di rumah sakit bahwa audit medis dilakukan dengan memprioritaskan semua staf untuk menghilangkan blaming (menyalahkan), naming (menyebut atau mencari siapa yang salah), dan shaming (mempermalukan) atau mengakui kesalahan. Untuk mampu belajar dari kesalahan harus ditekankan pada upaya mencari apa yang salah, mengapa kesalahan tersebut dapat terjadi, dan apa yang bisa dilakukan untuk memperbaiki kesalahan.

Sistem budaya keselamatan yang terdapat dalam organisasi dapat bersifat positif dengan adanya komunikasi terbuka yang berdasarkan nilai-nilai organisasi dan kepercayaan serta adanya persepsi yang didukung oleh anggota organisasi atau individu dalam suatu organisasi (Hammer et al., 2011)

\section{PENUTUP}

\section{KESIMPULAN}

Budaya keselamatan pasien dapat diukur melalui standar pengukuran budaya keselamatan pasien yang dikembangkan beberapa organisasi dalam memberikan suatu pelayanan yang aman dan bebas dari cedera. Dalam meningkatkan budaya keselamatan pasien, dapat memperkecil terjadinya resiko cedera pada pasien yang membuat kualitas dari pemberian asuhan keperawatan menurun.

\section{SARAN}

Mengingat pentingnya peningkatan budaya keselamatan pasien oleh perawat di rs, maka disarankan agar perawat memliki rasa kepemimpinan dan bekerja sama yang baik kepada sesama tenaga medis, tidak hanya pada sesama perawat tetapi kepada semua tenaga medis lainnya. Agar terciptanya budaya keselamatan pasien seperti yang diinginkan. 


\section{DAFTAR PUSTAKA}

Amarapathy, M., Sridharan, S., Perera, R., \& Handa, Y. (2013). Factors Affecting Patient Safety Culture In A Tertiary Care Hospital In Sri Lanka. 2(3), 173-179.

Herawati, Y. T. (2015). BUDAYA KESELAMATAN PASIEN DI RUANG RAWAT INAP RUMAH SAKIT $X$ KABUPATEN JEMBER. Jurnal IKESMA. 11(1). 5260.

Iriviranty, A. (2015). Analisis Budaya Organisasi dan Budaya Keselamatan Pasien Sebagai Langkah Pengembangan Keselamatan Pasien. Jurnal Administrasi Rumah Sakit. 1(3). 196-206.

Kartika. Wulan. (2013). Analisis Pengaruh Gaya Kepemimpinan Direktur terhadap Budaya Keselamatan Pasien di RS Hermina Pandanaran. Jurnal Manajemen Kesehatan. 3(2).

Mudayana, A. A. (2014). PERAN ASPEK ETIKA TENAGA MEDIS DALAM PENERAPAN BUDAYA KESELAMATAN PASIEN DI RUMAH SAKIT. Supplemen Majalah Kedokteran Andalas. 37(1). 69-74.

Najihah. (2018). Budaya Keselamatan Pasien Dan Insiden Keselamatan Pasien Di Rumah Sakit: Literature Review. Journal of Islamic Nursing, 3(1).

Pujilestari, A. Maidin, A. Anggraeni, R. (2014). BUDAYA KESELAMATAN PASIEN DI INSTALASI
RAWAT INAP RSUP DR. WAHIDIN SUDIROHUSODO KOTA MAKASSAR. JURNAL MKMI. 1(1). 57-64.

Simamora, R. H., \& Fathi, A. (2019). The Influence Of Training Handover Based SBAR Communication For Improving Patients Safety. Indian journal of public health research \& development, 10(9), 1280-1285.

Wulandari, M. R. Yulia, S. Triwijayanti, R. (2019). Peningkatan Budaya Keselamatan Pasien Melalui Peningkatan Motivasi Perawat dan Optimalisasi Peran Kepala Ruang. Jurnal Kepemimpinan dan Manajemen Keperawatan. 2(2). 58-66.

Yarnita, Y. Maswarni. (2019). BUDAYA KESELAMATAN PASIEN PADA PERAWAT DI INSTALASI PERAWATAN INTENSIVE RSUD ARIFIN ACHMAD PROVINSI RIAU. Jurnal Keperawatan Priority. ISSN 2614-4719. 2(2). 109-119.

Yasmi, Y. Thabrany, H. (2018). Faktor-Faktor yang Berhubungan dengan Budaya Keselamatan Pasien di Rumah Sakit. Jurnal ARSI. 4(2). 98-109. 